\title{
Concentration, enrichment and distribution of heavy metals in surface sediments of the Tangier Bay, Morocco
}

\author{
MARÍA ROCÍO RODRÍGUEZ-BARROSO ${ }^{1}$, YOUSSEF BENHAMOU ${ }^{1}$, \\ BOUCHTA EL MOUMNI ${ }^{2}$, DOLORES COELLO ${ }^{1}$ and JOSÉ LUIS GARCÍA-MORALES ${ }^{1}$ \\ ${ }^{1}$ Department of Environmental Technologies, University of Cadiz, 11510. Puerto Real, Spain. \\ E-mail: rocio.rodriguez@uca.es \\ ${ }^{2}$ Department of Earth Sciences and Oceanology, University of Abdelmalek Essaadi Tangier, 416, \\ Tangier, Morocco.
}

\begin{abstract}
SUMMARY: The distribution, enrichment, and accumulation of heavy metals in the surface sediments of the Tangier Bay, Morocco, were investigated. Surface sediment samples from eleven locations in the Bay of Tangier were collected in 2007 and characterized for grain size, organic matter and metal content (e.g. $\mathrm{Fe}, \mathrm{Mn}, \mathrm{Cr}, \mathrm{Cu}, \mathrm{Ni}, \mathrm{Pb}, \mathrm{Zn}$ and $\mathrm{Cd}$ ). The evaluation of the heavy metal contamination status of the bay showed minor enrichment by the enrichment factors (EF) calculation, corroborated by the metal pollution index (MPI). The results of a Pearson correlation showed high positive correlations among organic carbon and most metals $(0.788<r<0.939)$ and cluster analysis grouped the stations inside the harbour (stations 1,10 and 9) and in the vicinity of the principal rivers in the bay (stations 3 and 11), which showed the highest concentrations of metal content. The main sources of contamination are domestic and industrial effluents, which arise due to the lack of sewage treatment. However, these areas could not be classified as polluted when the data were compared with sediment quality guidelines (USEPA, 1997).
\end{abstract}

Keywords: metals, contamination, sediments, Tangier Bay, enrichment factors, Tangier Harbour, Morocco.

RESUMEN: CONCENTRACIÓN, ENRIQUECIMIENTO Y DISTRIBUCIÓN DE METALES PESADOS EN SEDIMENTOS DE LA BAHÍA DE TÁNGer, MARruecos. - Se ha investigado la distribución y acumulación de metales pesados en sedimentos superficiales de la bahía de Tánger, Marruecos. Se tomaron 11 muestras de sedimentos superficiales ubicadas en la bahía de Tánger durante el año 2007 y se analizaron los metales ( $\mathrm{Fe}, \mathrm{Mn}, \mathrm{Cr}, \mathrm{Cu}, \mathrm{Ni}, \mathrm{Pb}, \mathrm{Zn}$ y Cd), materia orgánica y distribución granulométrica. El estado de contaminación por metales de la bahía, se evaluó mediante el cálculo del factor de enriquecimiento (EF) y en general mostró bajo enriquecimiento, corroborado por el uso del índice de polución metálica (MPI). Los resultados de la correlación de Pearson presentaron una correlación significativa importante entre el carbono orgánico y la mayoría de los metales $(0.788<r<0.939)$. El análisis clúster agrupó las estaciones dentro del puerto (estaciones 1,10 y 9 ) y en las proximidades de los ríos que desembocan en la bahía (estaciones 3 y 11), que mostraron la mayor concentración del contenido de metales. Las principales fuentes de contaminación fueron los efluentes domésticos e industriales, como consecuencia del escaso tratamiento de estos vertidos. Sin embargo, esta zona no puede ser clasificada como contaminada al comparar los datos con las normas de calidad de sedimentos (USEPA, 1997).

Palabras clave: metales, contaminación, sedimentos, bahía de Tánger, factor de enriquecimiento, puerto de Tánger, Marruecos.

\section{INTRODUCTION}

Tangier Harbour is strategically located on the northwestern part of the Moroccan coast and faces the key trade waterway running between the Atlantic
Ocean and the Mediterranean Sea, the Gibraltar Strait. Until recently it was the largest international sea port in Morocco. In 2007, a new port situated about $40 \mathrm{~km}$ east of the city of Tangier was opened mainly for container transport (<www.TMSA.ma $>$ ). 


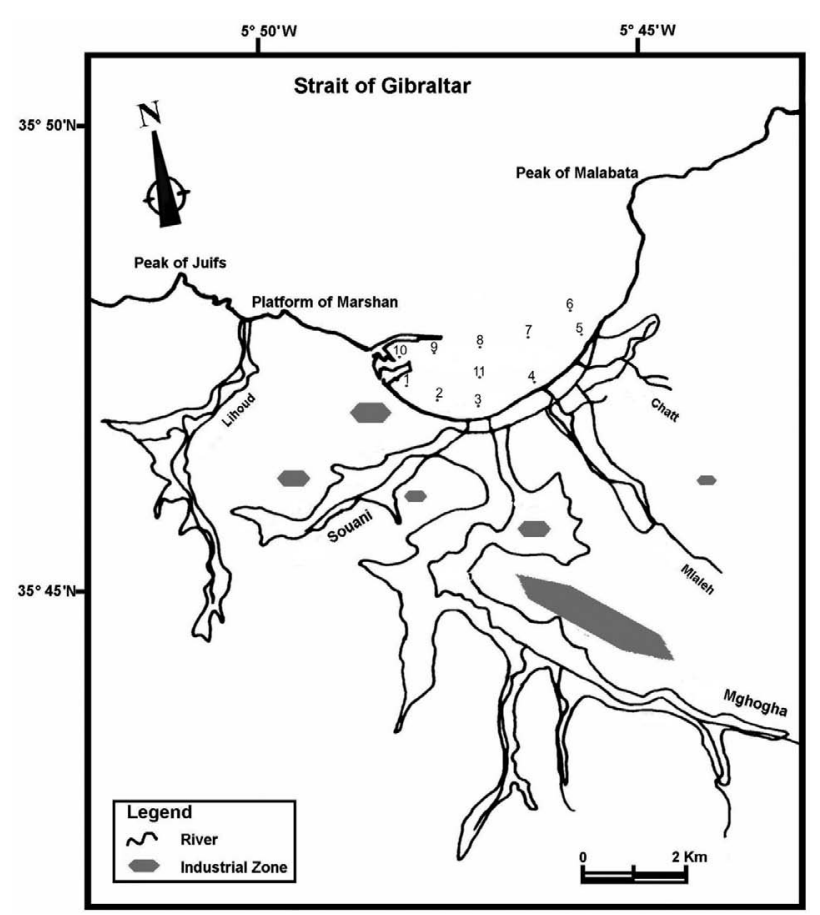

FIG. 1. - Location of sampling stations and geographical situation of the study area.

Tangier is the largest industrial city in northern Morocco, with a population of over 1 million. It receives water flows from four rivers (Fig. 1), namely the River Souani, the River Mghogha, the River Mlaleh and the River Chatt (Achab et al., 2007), which run through the heart of metropolitan Tangier. There was no sewage system until 2007 and all wastewater effluents were directly discharged untreated into nearby rivers (Rodríguez-Barroso et al., 2009). During most years, these rivers do not have a significant fresh water discharge and instead serve as the main pathway for urban runoff and sewage and industrial waste water discharge into the Bay of Tangier. In 2006, the Tangier city authorities started to construct sewage systems with an outfall in the west of the bay, and the household connection to the sewage system at the end of 2007 reached about $40 \%$ of the wastewater discharges (AMENDIS, 2005). Today, over $60 \%$ of domestic wastewater is still directly being discharged untreated into rivers. Moreover, there are several industrial parks (e.g. textile manufacturing plants, agro-food processing, and to a less extent chemicals, metals and wood processing factories) located in the nearby Mghogha complex that contribute a significant amount of untreated and / or minimally treated wastewater to the rivers and ultimately to the bay. This situation has created a great threat to public health and has impacted the biological and geochemical conditions of all four rivers, the bay and the harbour. In 2007 a sewage treatment plant was built to resolve the untreated wastewater problem. The sewage systems with an outfall in the west of the Bay were finished in late 2008.
It is well known that heavy metal concentrations in harbour or estuarine sediments are usually quite high due to anthropogenic metal loadings carried by rivers or their tributaries (Paetzel et al., 2003; Muniz et al., 2004; Guerra-García and García-Gómez, 2005). The sediments serve as a metal pool that-depending on the environmental conditions or processes - can retain metals or release metals to the overlying water via natural or anthropogenic processes. The metals released into the water column can cause adverse health effects to the ecosystems (Poulton et al., 1996; Fatoki and Mathabatha, 2001; McCready et al., 2006). Moreover, marine organisms or biota can take up metals, in turn enhancing the potential of some metals entering the food chain.

Very few studies have been made on harbour or estuarine sediments in northern Morocco. Some authors have focused on sediments from rivers flowing into the Tangier Bay, mainly from the Rivers Souani and Mghogha (e.g. El Hatimi, 2002; El Aouarram et al., 2008; Rodríguez-Barroso et al., 2009). Furthermore, El Arrim (2001) and Achab et al. (2005, 2007) studied sediments in the Tangier Bay. However, all of these studies were previous to the building of the treatment plant and the outfall.

A study of concentration, enrichment and distribution of heavy metals in Tangier Bay sediments is important in order to assess the state of contamination of the area and to estimate the possible influence of anthropogenic activities on harbour waters (Hung and Hsu, 2004; Morillo et al., 2004; Chen et al., 2007). In the present study, the physical and chemical properties of sediments in the Harbour and Tangier Bay were characterized, including mud and sand composition, organic content (OC) and the distribution of Fe, Mn, $\mathrm{Cr}, \mathrm{Cu}, \mathrm{Ni}, \mathrm{Pb}, \mathrm{Zn}$ and $\mathrm{Cd}$. The extent of metal contamination was assessed using the enrichment factor (EF) and the metal pollution index (MPI) (Reddy et al., 2004; Selvaraj et al., 2004; Usero et al., 2000). A statistical correlation analysis between relevant sediment characteristics and sediment metal concentrations was performed to determine the possible factors controlling trace metal concentration in the Tangier Bay sediments.

\section{MATERIALS AND METHODS}

\section{Sample collection}

Surface sediment samples were collected from eleven stations in the Tangier Bay (Fig. 1, GPS geographic coordinates position in Table 1), including four sampling points in the vicinity of the mouths of the four rivers that flow into the bay (station 3 near to the Rivers Souani and Mghogha; station 4 near to the River Mlaleh; station 5 near to the River Chatt) and three sampling points next to the harbour (stations 1, 9 and 10). The other four samples were collected in the middle of the bay (stations 6, 7, 8 and 11) in a profile along the river influence. The sampling depths of stations 1 to 5 and 11 were below $7.5 \mathrm{~m}$ and the depths of stations 
TABLE 1. - Location of the sampling stations and characteristics in the sediment of all stations studied in Tangier Bay.

\begin{tabular}{|c|c|c|c|c|c|}
\hline \multirow[b]{2}{*}{ Station } & \multicolumn{2}{|c|}{ Location } & \multicolumn{2}{|c|}{ Grain size } & \multirow{2}{*}{$\underset{\%}{\mathrm{OC}}$} \\
\hline & on & W & $\begin{array}{r}\% \mathrm{Mud} \\
(<0.063 \mathrm{~m}\end{array}$ & $\begin{array}{l}\% \text { sand } \\
63-2 \mathrm{~mm})\end{array}$ & \\
\hline 1 & $35^{\circ} 47.097^{\prime}$ & $05^{\circ} 47.861^{\prime}$ & 58.35 & 41.65 & 0.87 \\
\hline 2 & $35^{\circ} 46.929^{\prime}$ & $05^{\circ} 47.519^{\prime}$ & 88.53 & 11.47 & 0.58 \\
\hline 3 & $35^{\circ} 46.766^{\prime}$ & $05^{\circ} 47.028^{\prime}$ & 26.27 & 73.73 & 1.37 \\
\hline 4 & $35^{\circ} 47.056^{\prime}$ & $05^{\circ} 46.180^{\prime}$ & 40.49 & 59.51 & 0.58 \\
\hline 5 & $35^{\circ} 48.094^{\prime}$ & $05^{\circ} 45.073^{\prime}$ & 3.13 & 96.87 & 0.13 \\
\hline 6 & $35^{\circ} 48.146^{\prime}$ & $05^{\circ} 45.679^{\prime}$ & 13.76 & 86.24 & 0.69 \\
\hline 7 & $35^{\circ} 47.358^{\prime}$ & $05^{\circ} 46.571^{\prime}$ & 3.80 & 96.20 & 0.32 \\
\hline 8 & $35^{\circ} 47.401$ & $05^{\circ} 47.017^{\prime}$ & 8.42 & 91.58 & 0.20 \\
\hline 9 & $35^{\circ} 47.301^{\prime}$ & $05^{\circ} 47.329^{\prime}$ & 43.32 & 56.68 & 1.13 \\
\hline 10 & $35^{\circ} 47.357^{\prime}$ & $05^{\circ} 47.979$ & 80.24 & 19.76 & 1.56 \\
\hline 11 & $35^{\circ} 47.097^{\prime}$ & $05^{\circ} 47.861^{\prime}$ & 57.82 & 42.18 & 0.81 \\
\hline
\end{tabular}

6 to 10 were $18,11.5,14.5,13$ and $11 \mathrm{~m}$, respectively. These stations were chosen because they are located in the outlet of the four rivers that are the major contributories to the input of sewage into the bay.

The sampling campaign was carried out in October 2007, and about $2 \mathrm{~kg}$ of sediment samples were obtained using a van Veen dredge grab sampler. Samples were transferred to acid-washed plastic bags and placed in a cooler at $4^{\circ} \mathrm{C}$, and then transported to the laboratory for analysis.

\section{Sample processing}

Sediment samples were first dried in an oven at $60^{\circ} \mathrm{C}$ for at least $24 \mathrm{~h}$. The dried sediments were ground to powder using an agate mortar and pestle. The particles with a size of less than $63 \mu \mathrm{m}$ were collected and used for the trace metal analysis according to the procedures published by Bellucci et al. (2002). A sediment sample of about $0.25 \mathrm{~g}$ dry weight was digested with a mixture of concentrated acids before analysis $\left(\mathrm{H}_{2} \mathrm{O}_{2}: \mathrm{HCl}: \mathrm{HNO}_{3}=2: 3: 9 \mathrm{v} / \mathrm{v}\right.$ ) (duplicate digestions were made for each sample); a Milestone Ethos 1600 model microwave oven was used.

\section{Sample analysis}

Particle size was determined by wet sieving after elimination of the organic fraction with $\mathrm{H}_{2} \mathrm{O}_{2}$, to sepa-

TABLE 2. - Comparison of the analytical results of the reference material (MESS-3 and PACS-2, National Research Council, Canada) with the certified data. Detection limits.

\begin{tabular}{lccccc}
\hline & \multicolumn{2}{c}{ MESS-3 } & \multicolumn{2}{c}{ PACS-2 } & \\
Element & $\begin{array}{c}\text { Certified } \\
\text { value }\end{array}$ & $\begin{array}{c}\text { Measured } \\
\text { value }\end{array}$ & $\begin{array}{c}\text { Certified } \\
\text { value }\end{array}$ & $\begin{array}{c}\text { Measured } \\
\text { value }\end{array}$ & $\begin{array}{c}\text { Detection } \\
\text { limits }\end{array}$ \\
\hline $\mathrm{Fe}(\%)$ & 4.34 & 3.98 & 4.09 & 3.58 & 1.00 \\
$\mathrm{Mn}\left(\mathrm{mg} \mathrm{kg}^{-1}\right)$ & 324 & 293 & 440 & 316 & 0.100 \\
$\mathrm{Cr}\left(\mathrm{mg} \mathrm{kg}^{-1}\right)$ & 105 & 78.1 & 90.7 & 55.4 & 0.500 \\
$\mathrm{Cu}\left(\mathrm{mg} \mathrm{kg}^{-1}\right)$ & 33.9 & 29.1 & 310 & 289.1 & 0.600 \\
$\mathrm{Ni}\left(\mathrm{mg} \mathrm{kg}^{-1}\right)$ & 46.9 & 46.5 & 39.5 & 39.7 & 0.700 \\
$\mathrm{~Pb}\left(\mathrm{mg} \mathrm{kg}^{-1}\right)$ & 21.1 & 19.6 & 183 & 171 & 0.004 \\
$\mathrm{Zn}\left(\mathrm{mg} \mathrm{kg}^{-1}\right)$ & 159 & 152 & 364 & 384 & 0.500 \\
$\mathrm{Cd}\left(\mathrm{mg} \mathrm{kg}^{-1}\right)$ & 0.240 & 0.277 & 2.110 & 2.154 & 0.005 \\
\hline
\end{tabular}

rate sand from the fine fractions. Wet sediment samples were placed in an oven at $105^{\circ} \mathrm{C}$ and heated to a constant weight. Organic carbon (\% OC) was determined by mineralization of the organic matter to $\mathrm{CO}_{2}: 0.2-0.5$ $\mathrm{g}$ of sediment was oxidized with potassium dichromate (Gaudette et al., 1974).

Heavy metals (e.g. Fe, $\mathrm{Mn}, \mathrm{Cr}, \mathrm{Cu}, \mathrm{Ni}, \mathrm{Pb}, \mathrm{Zn}$ and $\mathrm{Cd}$ ) in digested sediment samples were determined by flame atomic absorption spectrometry (FAAS-Perkin Elmer type 100). For $\mathrm{Fe}, \mathrm{Mn}, \mathrm{Ni}, \mathrm{Cu}, \mathrm{Cr}, \mathrm{Cd}$, and $\mathrm{Zn}$, the flame atomic absorption spectroscopy technique was employed; for $\mathrm{Cd}$, the graphite furnace technique was used; detection limits are shown in Table 2. Calibration standards were regularly performed to evaluate the accuracy of the analytical method. Two certified reference standard sediments, MESS-3 and PACS-2, from the National Research Council of Canada were used to test the analytical and instrument accuracy of the method. The results indicate good agreement between certified and analytical values (recovery was over 94\% for MESS-3 and over 90\% for PACS-2, except for $\mathrm{Cr}$ and $\mathrm{Mn}$ in both cases). The statistical techniques of the Pearson matrix to test the relationship between sediment characteristics and trace metal concentrations and cluster analysis were performed using the Statistical Program for Social Sciences (version 14.0 for Windows).

\section{RESULTS}

\section{Sediment characteristics}

Table 1 presents the values of sediment characteristics in the sediments of all stations analyzed in the Tangier Bay. Texturally, mud $(<0.063 \mathrm{~mm})$ prevailed in the sediments from stations 2 and 10, varying between $80.2 \%$ and $88.5 \%$. Sand $(>0.063 \mathrm{~mm})$ showed maximum values at stations $3,5,6,7$ and 8 ranging between 73.7 and $96.8 \%$, while stations 1 , and 11 were characterized as slightly sandy mud and stations 4 and 9 were muddy sand.

\section{Organic carbon}

The organic carbon in sediments of the Tangier Bay ranged from $0.13 \%$ (station 5) to $1.56 \%$, (Station 10), with an overall value of $0.75 \%$ (Table 1). Samples in the vicinity of the port (stations 1,9 and 10) showed the highest values, in addition to station 3 around the mouths of the main rivers (Souani and Mghogha). Sample 11, in the middle of the bay and lined with station 3, also showed a relatively high OC $(0.81 \%)$, probably due to the influence of both the river mouths and the port.

\section{Metal contamination assessment}

The primary goal of this study was to assess the contamination of heavy metals in sediments of the 

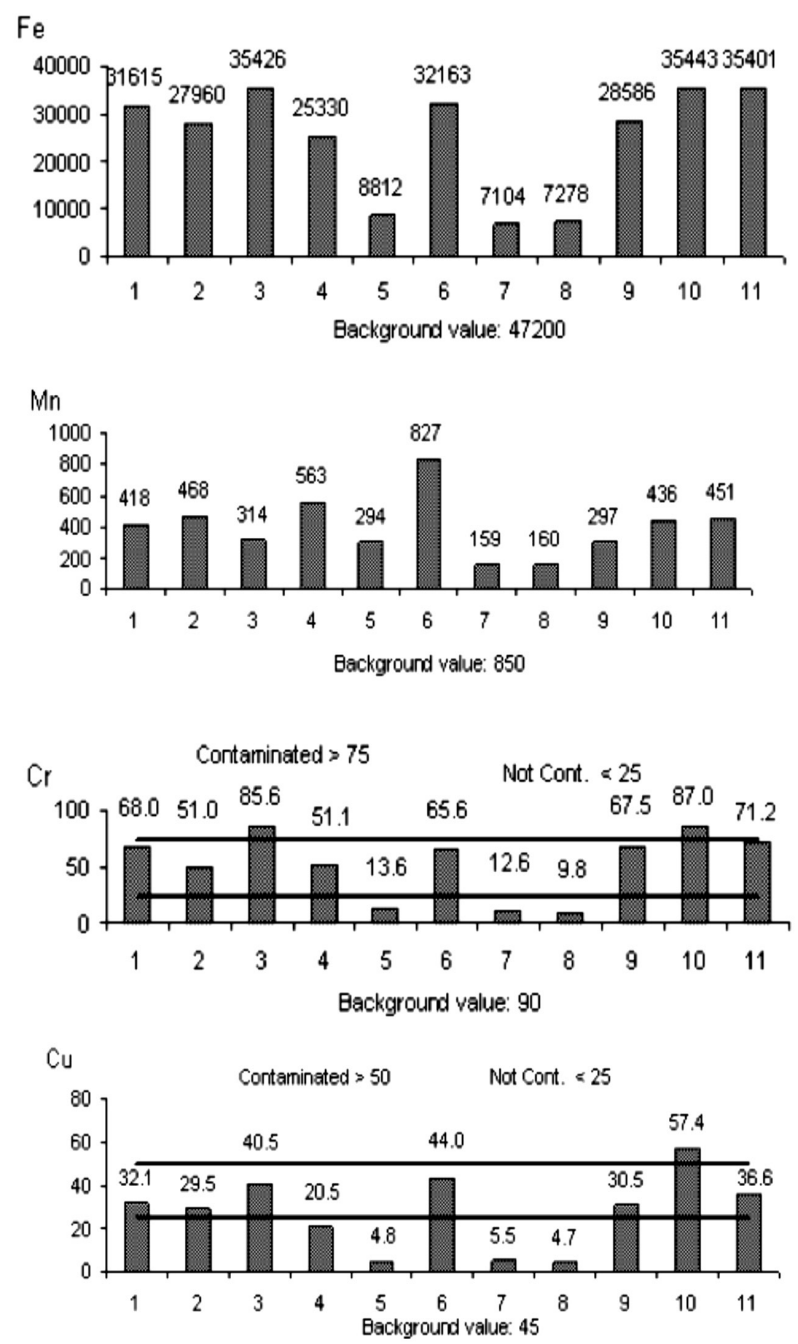

FIG. 2. - Spatial distribution of $\mathrm{Fe}, \mathrm{Mn}, \mathrm{Cr}$ and $\mathrm{Cu}$ concentrations (mg kg-1, dry mass). Background values (Turekian and Wedepohl, 1961); Lines indicate the limit values for contaminated (upper)/not contaminated (low) (USEPA, 1997).

Tangier Bay. The sediment quality guideline (SQG) was established to identify the level of contamination by heavy metals in marine sediments (USEPA, 1997), because there is currently no Moroccan SQG. To assess the metal contamination in surface sediments the concentrations of the most relevant toxic metals $(\mathrm{Cr}$, $\mathrm{Cu}, \mathrm{Ni}, \mathrm{Pb}, \mathrm{Zn}$ and $\mathrm{Cd}$ ) measured in the sediments were compared with the SQG established by USEPA.

As seen in Figures 2 and 3, heavy metals measured in the surface sediments in the Tangier Bay were almost all below the contamination levels, with the exception of $\mathrm{Cr}$ (St 3 and 10), $\mathrm{Cu}(\mathrm{St} \mathrm{10})$, and $\mathrm{Ni}$ (St 6), which exceeded these levels. However, the $\mathrm{Pb}$ and $\mathrm{Cd}$ contents for the stations were below the non-pollution level, indicating a low significance of both metals.

A cluster analysis was carried out to identify any analogous behaviour patterns between the sites (Fig. 4). Two principal clusters emerged: (1) stations 5, 7 and 8 with very little relevance around the Chatt mouth
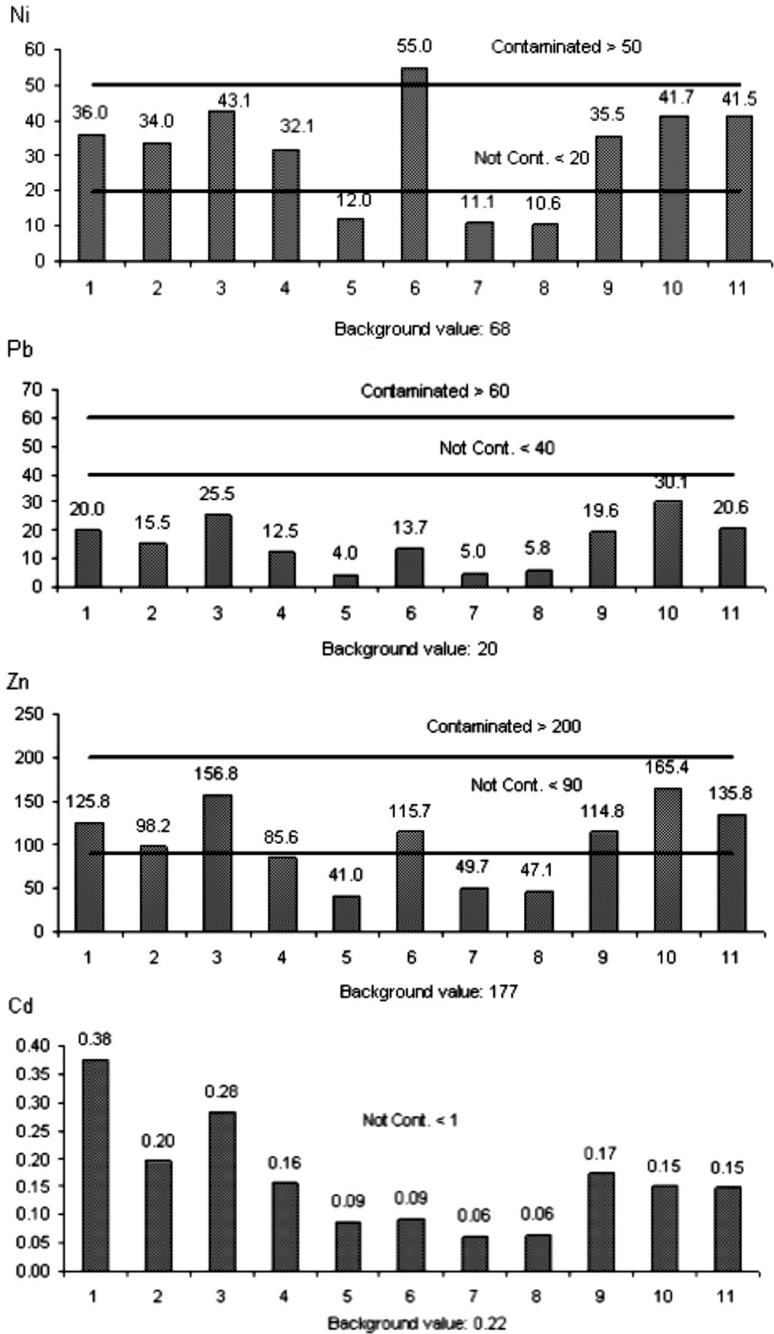

FIG. 3. - Spatial distribution of $\mathrm{Ni}, \mathrm{Pb}, \mathrm{Zn}$ and $\mathrm{Cd}$ concentrations (mg kg-1, dry mass). Background values (Turekian and Wedepohl, 1961); Lines indicate the limit values for contaminated (upper)/not contaminated (low) (USEPA, 1997).

and in the central part of the bay; and (2) other samples grouped in turn into two sets. The first set (stations 3, 11 and 10) included sites in the vicinity of the river mouths and inside the harbour, reflecting the importance of discharge of untreated industrial and municipal waste from the mouths of the Rivers Souani and Mghogha, which both drain very close $(<0.5 \mathrm{~km})$, focusing their discharges in the same area. The second set (stations 1, 6, 2, 9 and 4) showed concentrations in the range of values between the two defined limits according to USEPA (1997).

Pearson correlation analysis was applied to test the relationship among contaminants and sediment characteristics (Table 3 ). The results showed that these metals were strongly interrelated $(P<0.01)$, with correction coefficients ranging from 0.609 to 0.964 at the 99\% confidence level. A significant correlation was also found between organic carbon vs. $\mathrm{Fe}$ and both vs. all metals (ranging from 0.788 to $0.955, P<0.01$ ), 
TABLE 3. - Pearson matrix for sediment characteristics and metal concentrations.

\begin{tabular}{|c|c|c|c|c|c|c|c|c|c|c|}
\hline Station & $\begin{array}{l}\mathrm{Fe} \\
(\%)\end{array}$ & $\underset{\left(\mathrm{mg} \mathrm{kg}^{-1}\right)}{\mathrm{Mn}}$ & $\begin{array}{c}\mathrm{Cr} \\
\left(\mathrm{mg} \mathrm{kg}^{-1}\right)\end{array}$ & $\begin{array}{c}\mathrm{Cu} \\
\left(\mathrm{mg} \mathrm{kg}^{-1}\right)\end{array}$ & $\begin{array}{c}\mathrm{Ni} \\
\left(\mathrm{mg} \mathrm{kg}^{-1}\right)\end{array}$ & $\begin{array}{c}\mathrm{Pb} \\
\left(\mathrm{mg} \mathrm{kg}^{-1}\right)\end{array}$ & $\underset{\left(\mathrm{mg} \mathrm{kg}^{-1}\right)}{\mathrm{Zn}}$ & $\begin{array}{c}\mathrm{Cd} \\
\left(\mathrm{mg} \mathrm{kg}^{-1}\right)\end{array}$ & Mud & Sand \\
\hline $\mathrm{Mn}$ & - & & & & & & & & & \\
\hline $\mathrm{Cr}$ & $0.955^{*}$ & - & & & & & & & & \\
\hline $\mathrm{Cu}$ & $0.945^{*}$ & - & $0.891^{*}$ & & & & & & & \\
\hline $\mathrm{Ni}$ & $0.927^{*}$ & - & $0.845^{*}$ & $0.964^{*}$ & & & & & & \\
\hline $\mathrm{Pb}$ & 0.918 * & - & $0.936^{*}$ & $0.836^{*}$ & $0.764^{*}$ & & & & & \\
\hline $\mathrm{Zn}$ & $0.955^{*}$ & - & $0.955^{*}$ & 0.936 * & $0.873^{*}$ & $0.964^{*}$ & & & & \\
\hline $\mathrm{Cd}$ & - & - & $0.609 *$ & - & - & $0.655^{*}$ & - & & & \\
\hline Mud & - & $0.627^{*}$ & - & - & - & - & - & - & & \\
\hline Sand & - & $-0.627^{*}$ & - & - & - & - & - & - & - & \\
\hline $\mathrm{OC}$ & $0.879^{*}$ & - & $0.934^{*}$ & $0.861 *$ & $0.788^{*}$ & $0.939^{*}$ & $0.934^{*}$ & 0.647 & - & - \\
\hline
\end{tabular}

- not significant at $P>0.05$; others are significant; * Significant at $P<0.01$

indicating anthropogenic origin, except for Mn, which showed a significant positive correlation with fines and a negative one with sand.

\section{Enrichment factor (EF)}

The enrichment factor (EF) was used as an index to examine the extent of metal contamination in the sediments of the Tangier Bay. Mathematically, EF is a concentration ratio of measured metal to iron in the sample of interest divided by the background metal/iron background concentration ratio. EF is expressed as:

$$
E F=\frac{(\mathrm{Me} / \mathrm{Fe})_{\text {sample }}}{(\mathrm{Me} / \mathrm{Fe})_{\text {background }}}
$$

where $(\mathrm{Me} / \mathrm{Fe})_{\text {sample }}$ is the metal to $\mathrm{Fe}$ ratio in the samples of interest, and $(\mathrm{Me} / \mathrm{fe})_{\text {background }}$ is the natural background value of the metal to Fe ratio. Because we do not have Fe and heavy metal background values for our study area, the average crust metal values from Turekian and Wedepolh (1961) were adopted (shown in Figs. 2 and 3).

The advantage of using enrichment factor (EF) analysis is that it is possible to establish a contamination guideline. This technique has been well applied in several studies to assess metal contamination in marine sediments (Khaled et al., 2006; AcevedoFigueroa, et al., 2006; Ghrefat and Yusuf, 2006). EF values were interpreted as suggested by Birch (2003), where $\mathrm{EF}<1$ indicates no enrichment; $<1-3$ is minor; $3-5$ is moderate; $5-10$ is moderately severe; $10-25$ is severe; $25-50$ is very severe; and $>50$ is extremely severe. EF values for all the metals in sediments of Tangier Bay showed minor or no enrichment $(\mathrm{EF}<1)$ (Table 5). The highest values correspond to stations 1 and 5 (for $\mathrm{Cd}$ ) and station 10 (for $\mathrm{Pb}$ ) and all were $<3$ (minor enrichment). EF values in this study were insignificant in comparison with other similar work (Kaoshiung harbour in Taiwan), which detected high $\mathrm{EF}$ values (between 2.8 for $\mathrm{Cr}$ and 23.5 for $\mathrm{Cd}$ ) in sediments in the vicinity of the mouth of a river which received a huge amount of metal discharge from nearby industrial plants and sewage discharges (Chen et al., 2007).

\section{Metal pollution index}

Another index that can reflect the status of environmental contamination is the metal pollution index (MPI), calculated according to Usero et al. (2000) with the formula:

$$
\mathrm{MPI}=\left(\mathrm{C} f_{1} \times \mathrm{C} f_{2} \times \ldots \times \mathrm{C} f_{n}\right)^{1 / \mathrm{n}},
$$

where $\mathrm{C} f_{n}$ is the concentration of the metal $n$ in the sample.

The MPI values of the 8 heavy metals in sediments of the study area are summarized in Table 5. The highest average MPI in Tangier Bay was at the station next to the harbour (station 1), and was very similar to that recorded by Rodríguez-Barroso et al. (2009) near the industrial complex in the River Mghogha, one of the natural outlets into the Tangier Bay (MPI =73.0). This index can provide a classification of the study areas according to the level of contamination. The order of stations from highest to lowest MPI values was St $1>\mathrm{St} 3>\mathrm{St} 6>\mathrm{St}$ $10>$ St 2>St 11>St 9; all were located in the west part of the bay, near the port and at the mouth of the most industrialized rivers. These results were very similar to those reported by Rodríguez-Barroso et al., (2009) for the same metals in the Rivers Souani and Mghogha, which discharges into the Tangier Bay (average MPI, 42 and 62 , respectively). They were also very similar to those reported for the same metals by Khaled et al. (2006) in Gulf of Suez sediments, next to effluents from mining, hydrocarbon refineries and other industries (minimum and average values, 35 and 72, respectively).

\section{DISCUSSION}

\section{Sediment composition}

The organic carbon in sediments in Tangier Bay was relatively low but was above the values reported by Wang et al. (2007) in Jiaozhou Bay (China), with an average of $0.37 \%$. The highest OC values were found next to the port (average 1.34\%). Sediment samples contained a high percentage of the finegrained fraction $(<0.063 \mathrm{~mm})$, although the values were quite low in comparison with those recorded in 
previous studies of sediments from rivers in northern Morocco that flow into this bay (ranges $0.28-9.46 \%$ ), which are influenced by a large industrial complex (Rodríguez-Barroso et al. 2009). It must be taken into account that, in agreement with Achab et al. (2007), the marine dynamics in the Tangier Bay causes a dilution and diminution in the concentration of organic matter in the sediments. However, this value is lower than those reported in Kaohsiung (Taiwan), which were between $3.2 \%$ and $9.7 \%$ organic matter (Chen et al. 2007).

Station 3, next to the mouth of the principal tributaries of the bay (Souni and Mghogha), showed a high amount of OC (1.37\%) due to sewage effluent discharged by the rivers (around 390000 equivalent inhabitants, AMENDIS, 2005). However, this value is lower than that reported by Rodríguez-Barroso et al. (2006) in surficial sediments from shipbuilding factories in Cadiz Bay (1.84-3.24\%).

The properties of sediments, including grain size and concentrations of organic carbon, are two critical factors influencing the metal distribution in sediments (Huang and Lin, 2003; Liaghati et al., 2003). As fine sediments and a high organic matter content are carriers of metals, samples around the port with a high fraction of fine sediment (2 and 10) or with muddy sand (stations 1 and 9) showed the highest metal concentrations, as did stations 3, 6 and 11, which are close to the river mouth or to the influence of the rivers (Mghogha and Chatt).

\section{Metal contents}

The mouths of the Rivers Souani and Mghogha and their area of influence are also characterized by high metal contents at station 3 with a sand composition and station 11 with a sandy mud composition. Both showed relatively high organic carbon contents and high levesl of $\mathrm{Cr}, \mathrm{Cu}, \mathrm{Ni}, \mathrm{Pb}$ and $\mathrm{Zn}$. In fact, the $\mathrm{Cr}$ and $\mathrm{Zn}$ contents in these samples were similar to those reported by Rodríguez-Barroso et al. (2008) in industries associated with shipbuilding in the Cadiz Bay (average $67.1 \mathrm{mg} \mathrm{kg}^{-1} \mathrm{Cr}$ and $138.5 \mathrm{mg} \mathrm{kg}^{-1}$ $\mathrm{Zn})$. However, the areas considered as receiving the highest heavy metal impact cannot be classified as

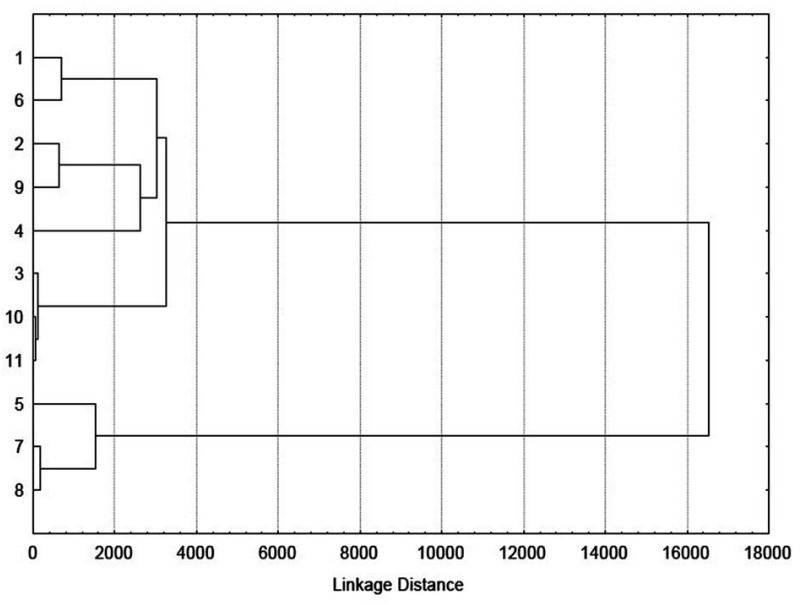

FIG. 4. - Dendrogram for hierarchical cluster analysis of 11 stations based on eight heavy-metal concentrations in Tangier Bay sediments.

contaminated by USEPA (1997) or by the calculation of enrichment factors, which showed minor and no metal enrichment.

Those results were expected according to MPI values, which revealed some areas of metal enrichment such as the harbours and areas next to the mouths of the main tributaries. However, according to the low EF values detected, the MPI values are relatively low and cannot be considered as alarming data. In these areas the metal concentrations are higher than those recorded by Rodríguez-Barroso et al. (2010) in sediments from southern Spain, with average MPI values of 15.3 (Cádiz Bay) and 19.3 (a marsh area). Cluster analysis (Fig. 4) also revealed a group consisting of stations 3 and 11 (in the vicinity of the discharge of the Rivers Souani and Mghogha) and station 10 (inside the port)The correlation analysis of metal concentration data show high positive correlations with organic carbon and with iron concentrations ( $\mathrm{Fe}$ vs $\mathrm{Cr}, \mathrm{Cu}$, $\mathrm{Ni}, \mathrm{Pb}$ and $\mathrm{Zn}$ ). This fact could indicate a common origin of metals, which are probably transported by the organic matter from the sewage effluents of urban influence, as reported by Rodríguez-Barroso et al. (2009) in sediments of the River Mghogha, probably due to a common contamination source coming from an industrial park.

TABLE 4. - Average metal concentrations found in sediments from different zones in north of Morocco and several harbours in the world.

\begin{tabular}{|c|c|c|c|c|c|c|c|c|}
\hline Locations & $\mathrm{Pb}$ & $\mathrm{Cd}$ & $\mathrm{Cr}$ & $\mathrm{Cu}$ & $\mathrm{Zn}$ & $\mathrm{Ni}$ & Classified & Reference \\
\hline Tangier Bay & $4.0-30.1$ & $0.06-0.38$ & $9.8-85.6$ & $4.7-57.4$ & $41-165$ & $10.6-55.0$ & Uncont. & Present study \\
\hline Tangier Bay & $8-82$ & $\mathrm{nr}$ & $33-110$ & $9-58$ & $14-348$ & $14-52$ & Uncont. & Achab, et al., 2007 \\
\hline Nador Lagoon, north Morocco & $0-33$ & $0.1-0.5$ & $17-40$ & $1-38$ & $35-60$ & $\mathrm{nr}$ & Uncont. & Bellucci, et al., 2003 \\
\hline River Martil, north Morocco & $10.1-36.6$ & $0.06-0.18$ & $21.9-45.2$ & $10.4-732$ & $33.0-105$ & $\mathrm{nr}$ & Uncont. & Bellucci, et al., 2003 \\
\hline River Mghogha, north Morocco & $0-997$ & $0.99-129.3$ & $0.20-46.3$ & $0.0-1.089$ & $171-12.222$ & $\mathrm{nr}$ & Cont. & El Aouarram, et al., 2008 \\
\hline River Mghogha, north Morocco & $3.8-56.1$ & $0.1-0.4$ & $7.0-149.4$ & $5.1-67.1$ & $37.2-757.8$ & $10.7-64.9$ & $\mathrm{nr}$ & Rodríguez-Barroso et al., 2009 \\
\hline River Suani, north Morocco & $4.9-58.8$ & $0.1-0.5$ & $8.8-113.6$ & $6.5-65.3$ & $41.5-216.5$ & $11.0-36.8$ & $\mathrm{nr}$ & Rodríguez-Barroso et al., 2009 \\
\hline Kaohsiung Harbour, Taiwan & $9.5-470$ & $0.1-6.8$ & $0.2-900$ & $5-946$ & $52-1369$ & $\mathrm{nr}$ & Cont. & Chen et al., 2007 \\
\hline Ceuta Harbour, Spain & $10-516$ & $\mathrm{nr}$ & $13-381$ & $5-865$ & $29-695$ & $8-671$ & Cont. & Guerra-García \& García-Gómez, 2005 \\
\hline Cádiz Harbour & $5.1-86.9$ & $0.9-1.3$ & $0.1-14.9$ & $7.0-202.8$ & $21.2-378.3$ & $0.06-21.2$ & $\mathrm{nr}$ & Casado-Martínez et al., 2006 \\
\hline Cartagena Harbour & 486.7-1.397 & $6.8-98.5$ & $29.5-66.6$ & $171.1-665.9$ & $900.8-8.661$ & $15.3-29.0$ & Cont. & Casado-Martínez et al., 2006 \\
\hline
\end{tabular}

nr not reported; Cont.: Contaminated; Uncont.: Uncontaminated 
TABLE 5. - Enrichment factor of heavy metals in Tangier Bay sediments. Metal Pollution Index (MPI).

\begin{tabular}{|c|c|c|c|c|c|c|c|c|}
\hline Stations & $\mathrm{Mn}$ & $\mathrm{Cr}$ & $\mathrm{Cu}$ & $\mathrm{Ni}$ & $\mathrm{Pb}$ & $\mathrm{Zn}$ & $\mathrm{Cd}$ & MPI \\
\hline 1 & 0.73 & 1.13 & 0.53 & 0.79 & 1.50 & 1.06 & 2.55 & 75 \\
\hline 2 & 0.93 & 0.96 & 0.55 & 0.84 & 1.31 & 0.94 & 1.51 & 38 \\
\hline 3 & 0.49 & 1.27 & 0.60 & 0.84 & 1.70 & 1.18 & 1.72 & 48 \\
\hline 4 & 1.24 & 1.06 & 0.42 & 0.88 & 1.16 & 0.90 & 1.33 & 29 \\
\hline 5 & 1.85 & 0.81 & 0.29 & 0.95 & 1.06 & 1.24 & 2.11 & 12 \\
\hline 6 & 1.43 & 1.07 & 0.72 & 1.19 & 1.01 & 0.96 & 0.61 & 46 \\
\hline 7 & 1.24 & 0.93 & 0.40 & 1.08 & 1.66 & 1.86 & 1.82 & 11 \\
\hline 8 & 1.22 & 0.70 & 0.34 & 1.01 & 1.87 & 1.73 & 1.88 & 10 \\
\hline 9 & 0.58 & 1.24 & 0.56 & 0.86 & 1.62 & 1.07 & 1.29 & 34 \\
\hline 10 & 0.68 & 1.29 & 0.85 & 0.82 & 2.01 & 1.24 & 0.92 & 43 \\
\hline 11 & 0.71 & 1.05 & 0.54 & 0.81 & 1.37 & 1.02 & 0.90 & 36 \\
\hline
\end{tabular}

\section{Comparison with other zones}

Table 4 shows the average metal concentrations reported in sediments from different parts of northern Morocco and other harbours and bays in the world (Achab et al., 2007; Bellucci et al., 2003; Chen et al., 2007; GuerraGarcía and García-Gómez, 2005; Casado-Martínez et al., 2006). Sediments coming from northern Morocco (a salt marsh core from Nador) showed low metal concentrations and the authors suggested that they are probably very close to the natural background (Bellucci et al., 2003). These values are also very close to those found in this study. However, in other zones studied by the same authors (sediments from the River Martil), higher concentrations of heavy metals were found, probably due to a significant role of the urban and industrial settlements of Tétouan. The same characteristic was shown by the River Mghogha, which crosses the city of Tangier and is affected by the urban and industrial liquid and solid discharges from the industrial area of Tangier (around 70000 t/year of solid inputs), according to El Aouarram, et al. (2008). Levels of $\mathrm{Pb}, \mathrm{Cd}, \mathrm{Cu}$ and $\mathrm{Zn}$ in Tangier Bay were lower than those recorded by these authors in the River Mghogha, with the exception of $\mathrm{Cr}$, which showed higher levels in the bay. Another study in the Rivers Mghogha and Souani in the city of Tangier (Rodríguez-Barroso et al., 2009) revealed higher levels of $\mathrm{Pb}, \mathrm{Cr}$ and $\mathrm{Zn}$ than those recorded in this study, but levels of $\mathrm{Cd}$ and $\mathrm{Cu}$ were comparable or slightly lower and only levels of $\mathrm{Ni}$ in Tangier Bay were higher than those recorded in the River Souani. In another study in the Tangier Bay, Achab et al. (2007) recorded high values in the harbour and values very similar to those found in this study in the bay, and suggested that the concentrations were related to the routine activities of the port (rejection of hydrocarbons, chemicals products and other activities), as well as to the domestic and industrial effluents of anthropogenic origin. Higher values were obtained in the Kaohsiung harbours in Taiwan, with similar characteristics to those of the Tangier Bay, where over $70 \%$ of domestic wastewaters were still directly being discharged untreated into the rivers and several industrial parks considered as contaminated zones were located around the city of Kaohsiung (Chen $e t$ al., 2007). Others works related to contamination of sediments in Spanish harbours have reported higher values of $\mathrm{Cu}, \mathrm{Pb}, \mathrm{Cd}$ and $\mathrm{Zn}$ than in the Tangier Bay in Ceuta
(Guerra-Garcia and García-Gómez, 2005), Cartagena and Cádiz (Casado-Martínez et al., 2006). The $\mathrm{Cr}$ and $\mathrm{Ni}$ levels in the Tangier Bay were generally lower than those reported in the Cartagena and Cádiz harbours. Compared with these works, in the present study heavy metals did not show high values, probably due to the high hydrodynamic energy in the Tangier Bay, where the surges of NW direction reach the bay perpendicularly to the coast; the diffraction of these surges creates a side current responsible for the transport of the sediments towards the west of the bay (Achab et al., 2007). In general, the degree of marine contamination in Tangier remains relatively low in comparison with the sites described.

It is also important to emphasize the limited influence of the mouths of the Rivers Mlaleh and Chatt. This is obviously because these rivers are small and represent a minor percentage of the discharges collected. In fact, stations 4 and 5 showed no enrichment $(\mathrm{EF}<1)$ and MPI values were very low, although sample 4 seems to show a higher MPI value than sample 5. This was corroborated by cluster analysis, which grouped station 4 with samples that were fairly polluted by metals. The effect range-median (ERM) sediment quality guidelines in the United States, which represents the chemical level above which effects frequently occur to aquatic organisms (NOAA (NS\&T: National State and Trend Programme)) were also taken into account. Only station 6 (mouth of the River Chatt) had an Ni chemical level above which effects frequently occur to aquatic organisms (ERM $51.6 \mathrm{mg} \mathrm{kg}^{-1}$ ).

It is important to take into account that the outfall was built at the west side of the harbour. The predominant currents in the east could move and deposit pollutants inside the bay, and ultimately in sediments. The present study could be considered as a preliminary study of the possible influence of discharges by the outfall into the bay.

Therefore, proper treatment of industrial waste effluents and municipal wastewater is a better strategy for controlling metal sediments in the Tangier Bay. Results obtained from this study would be helpful in developing more effective watershed and bay management strategies for controlling metal discharges into the bay and developing a managerial protocol for the remediation of contaminated sediments. Finally, this work could be used to verify the possible impact that the outfall might have in the future. 


\section{ACKNOWLEDGEMENTS}

This research was supported by the Spanish International Development Cooperation Agency (AECID) within the framework of the Programme of Interuniversity and Scientific Research Cooperation between Spain and Morocco, Project "State of sediment in Tangier Bay previous to the operation of the WWTP", grant No. A/8192/07.

\section{REFERENCES}

Acevedo-Figueroa, D., B.D. Jiménez and C.J. Rodríguez-Sierra. 2006. Trace metals in sediments of two estuarine lagoons from Puerto Rico. Environ. Pollut., 141: 336-342.

Achab M., A. El Moumni, El Arrim, B.and Gutierrez Mas, J.M. - 2005. Répartition des faciés sédimentaires récents en milieu marin côtier: exemple des baies de Tanger (NW-Maroc) et de Cadix (SW-Espagne). Bull. Inst. Sci. Rabat, sec. Sci. Terre, 27.

Achab M., A. El Arrim, B. El Moumni and I. El Hatimi. - 2007. Metallic pollution affecting the bay of Tangier and its continental emissaries: anthropic impact. Thalassas, 23(2): 23-36.

AMENDIS. - 2005. La station de traitement des eaux usées de Tanger. Journée d'étude sur la Pollution Marine. Fondation SIGMA, 66-68.

Bellucci, L.G., M. Frignani, D. Paolucci and M. Ravanelli. - 2002. Distribution of heavy metals in sediments of the Venice Lagoon: the role of the industrial area. Sci. Total Environ., 295: 35-49.

Bellucci, L.G., B. El Moumni, F. Collavini, M. Frignani and S. Albertazzi. - 2003. Heavy metals in Morocco Lagoon and river sediments. J. Phys. IV France., 107: 139-142.

Birch, G. - 2003. A scheme for assessing human impacts on coastal aquatic environments using sediments. In: C.D. Woodcoffe, R.A. Furness (eds.), Coastal GIS 2003. Wollongong University Papers in Center for Maritime Policy, 14, Australia. <http:// www.ozestuaries.org/indicators/DEF_sediment_scheme.html>

Casado-Martínez, M.C., J.L. Buceta, M.J. Belzunce and T.A. DelValls. - 2006. Using sediment quality guidelines for dredged material management in commercial ports from Spain. Environ. Int., 32: 388-396

Chen, C.W., C.M. Kao, C.F. Chen and C.D. Dong. - 2007. Distribution and accumulation of heavy metals in the sediments of Kaohsiung Harbour, Taiwan. Chemosphere, 66: 1431-1440.

El Aouarram, A., M.D. Galindo, H. El Mai, J.J. Vicente, M. GarcíaVargas, M. Stitou, F. El Yousfi, M. Ammari, L. Ben Allal, M.D. Granado. - 2008. Distribution and source of trace metals in coastal water of the bay of Tangier (North West Morocco). Fresenius Environ. Bull., 17: 1688-1696.

El Arrim, A. - 2001. Contribution a l'étude du littoral de la baie de Tanger (Rif Nord Occidental-Marco). Approches sédimentologique, minéralogique, géochimie et impact de la dynamique sédimentaire. Thése de Doctorat National, Fac. Sciences et Techniques, Tanger, Maroc.

El Hatimi, I., M. Achab and B. El Moumni. - 2002. Impact des émissaires et et canalisation sur l'énvironment de la baie de Tanger (Maroc): approche géochimique. Bull. Inst. Sci. Rabat, sec. Sci. Terre, 24: 49-58.

Fatoki, O.S. and S. Mathabatha. - 2001. An assessment of heavy metal pollution in the East London and Port Elizabeth harbours. Water S.A., 27: 233-240.

Gaudette, H.E., W.R. Flight, L. Toner and D.W. Folger. - 1974. An inexpensive titration method for the determination of organic carbon in recent sediments. J. Sediment. Petrol., 44(1): 249-253.

Ghrefat, H. and N. Yusuf. - 2006. Assessing Mn, Fe, Cu, Zn and Cd pollution in bottom sediments of Wadi Al-Arab Dam, Jordan. Chemosphere., 65: 2114-2121.

Guerra-García, J.M. and J.C. García-Gómez. - 2005. Assessing pollution levels in sediments of a harbour with two opposing entrances. Environmental implications. J Environ. Manage., 77: 1-11.

Huang, K.M. and S. Lin. - 2003. Consequences and implication of heavy metal spatial variations in sediments of the Keelung River drainage basin, Taiwan. Chemosphere., 53: 1113-1121.

Hung, J.J. and C.L. Hsu. - 2004. Present state and historical changes of trace metal pollution in Kaoping coastal sediments, southwestern Taiwan. Mar. Pollut. Bull., 49: 986-998.

Khaled, A., A. El Nemr and A. El Sikaily. - 2006. An assessment of heavy-metal contamination in surface sediments of the Suez Gulf using geoaccumulation indexes and statistical analysis. Chem. Ecol., 22(3): 239-252.

Liaghati, T., M. Preda and M. Cox. - 2003. Heavy metal distribution and controlling factors within coastal plain sediments, Bells Creek catchment, southeast Queensland, Australia. Environ. Int., 29: 935-948

McCready, S., G.F. Birch and E.R. Long. - 2006. Metallic and organic contaminants in sediments of Sydney Harbour, Australia and vicinity-A chemical dataset for evaluating sediment quality guidelines. Environ. Int., 32: 455-465.

Morillo, J., J. Usero and I. Gracia. - 2004. Heavy metal distribution in marine sediments from the southwest coast of Spain. Chemosphere, 55: 431-442.

Muniz, P., E. Danula, B. Yannicelli, J. Garcia-Alonso, G. Medina and M.C. Bicego. - 2004. Assessment of contamination by heavy metals and petroleum hydrocarbons in sediments of Montevideo Harbour (Uruguay). Environ. Int., 29: 1019-1028.

NOAA SQuiRTs (Screening Quick Reference Tables). Office of response and restoration: NOAA's National Ocean Service. http:// response.Restoration.noaa.gov

Paetzel, M., G. Nes, L.O. Keifsen and H. Schrader. - 2003. Sediment pollution in the Vágen, Bergen harbour, Norway. Environ. Geol., 43: 476-483.

Poulton, D.J., W.A. Morris and J.P. Coakley. - 1996. Zonation of contaminated bottom sediments in Hamilton Harbour as defined by statistical classification techniques. Water Pollut. Res. J Can., 31: 505-528.

Reddy, M.S., S. Basha, V.G. Sravan Kumar, H. V. Joshiand G. Ramachandraiah. - 2004. Distribution, enrichment and accumulation of heavy metals in coastal sediments of Alang-Sosiya ship scrapping yard, India. Mar. Pollut. Bull., 48: 1055-1059.

Rodríguez-Barroso, M.R., M. Ramírez-del Solar, E. Blanco, J.M. Quiroga and J.L. García-Morales. - 2006. Thermal analysis in the evaluation of sediment pollution. Environ. Technol., 27: 1001-1009.

Rodríguez-Barroso, M.R., Ramírez-del Solar, E. Blanco, J.M. Quiroga and J.L. García-Morales. - 2008. Qualitative estimation of heavy metals in marine sediment using thermal analysis. Soil Sed. Contam., 17: 107-120

Rodríguez-Barroso, M.R., Y. Benhamou, B. El Moumni, I. El Hatimi, J.L. García-Morales. - 2009. Evaluation of metal contamination in sediments from north of Morocco: geochemical and statistical approaches. Environ. Monit. Assess., 159: 169-18

Rodríguez-Barroso, M.R., J.L García-Morales, D. Coello Oviedo, J.M. Quiroga, - 2010. An assessment of heavy metal contamination in surface sediment using statistical analysis. Environ. Monit. Assess., 163: 489-501

Selvaraj, K., V. Ram Mohan and P. Szefer. - 2004. Evaluation of metal contamination in coastal sediments of the Bay of Bengal, India: geochemical and statistical approaches. Mar. Pollut. Bull., 49: 174-185.

Turekian, K.K. and K.H. Wedepohl. - 1961. Distribution of the elements in some major units of the earth's crust. Bull. Geol. Soc. Am., 72: 175-192.

USEPA. - 1997. An SAB report: Review of the Agency's draft ecological risk assessment guidelines. Science Advisory Board United States Environmental Protection Agency. Washington, DC. EPA-SAB-EPEC-97-002.

Usero, J., A. García and J. Fraidías. - 2000. Calidad de las aguas y sedimentos del Litoral Andaluz. Junta de Andalucía, Consejería del Medio Ambiente, Sevilla.

Wang, X.C., H. Feng and H.Q. Ma. - 2007. Assessment of metal contamination in surface sediment of Jiaozhoy Bay, Qingdao, China. Clean, 35(1): 62-70.

Received November 1, 2008. Accepted July 26, 2010.

Published online November 13, 2010. 